\title{
NEW DATA CONCERNING THE AGE OF MESOZOIC LIMESTONE FROM SCĂRIŞOARA (BIHOR MOUNTAINS)
}

\author{
IOAN I. BUCUR ${ }^{1}$, BOGDAN P. ONAC ${ }^{2}$
}

\begin{abstract}
Microfacies and micropalaeontologic studies on some limestone samples collected within the Scărişoara Glacier Cave are presented. The investigation pointed out that the age of the limestone around Scărişoara Cave is of Upper Jurassic (Kimmeridgian) age and not Triassic as it was considered in most of the studies.
\end{abstract}

KEYWORDS: Mesozoic, limestone, microfacies, Scărişoara Glacier Cave, Bihor Mts., Romania

\section{Geographic and Geologic Setting}

Scărişoara Glacier Cave is located in the central area of the Bihor Massif (Apuseni Mountains). The area is a karst plateau bounded on the east and west by Ordâncuşa and Gârda Seacă valleys, respectively (Racoviță, 1927; Rusu et al., 1970) (Fig. 1).

Access to this region is provided by National Road 75 from both Oradea (125 km) and Cluj (146 km), connecting with a county road (18 km) at Gârda de Sus. This later road is not accessible during winter and early springtime.

A series of tourists reports and descriptions referring to the Scărişoara Glacier Cave (middle of the last century) were followed by two scientific papers. Both of them represented the results of an Austrian expedition in the Bihor Mountains financed by Archduke Albrecht (Schimdl, 1863). The first paper, published by geologist Peters in 1861, contains informations on the age of the limestone and its tectonic setting. Based on his investigations, Peters (1861) uphold a Jurassic-Neocomian age for the limestone around the Scărişoara Cave. The well-known geographer Adolf Schimdl wrote the second paper, which was printed in 1863. This book contains a geology review of the Bihor Mountains, and also a more detailed description of the cave.

After Racoviță's first monographic study on the Scărişoara Glacier Cave (1927), a number of articles were published by the researchers of the Speological Institute in Cluj as a result of an extremely detailed and systematic studiy on climatology, glaciology, and underground ecology. All their results, as well as some new investigations were compiled and presented in a recent monographic study (Racoviță and Onac, 2000).

\footnotetext{
1 "Babeş-Bolyai" University, Department of Geology, 1 Kogălniceanu str., 3400 Cluj-Napoca, Romania.

2 "Babeş-Bolyai" University, Department of Mineralogy 1 Kogălniceanu str. and Speological Institute "Emil Racoviță", Clinicilor 5, 3400 Cluj-Napoca, Romania.
} 

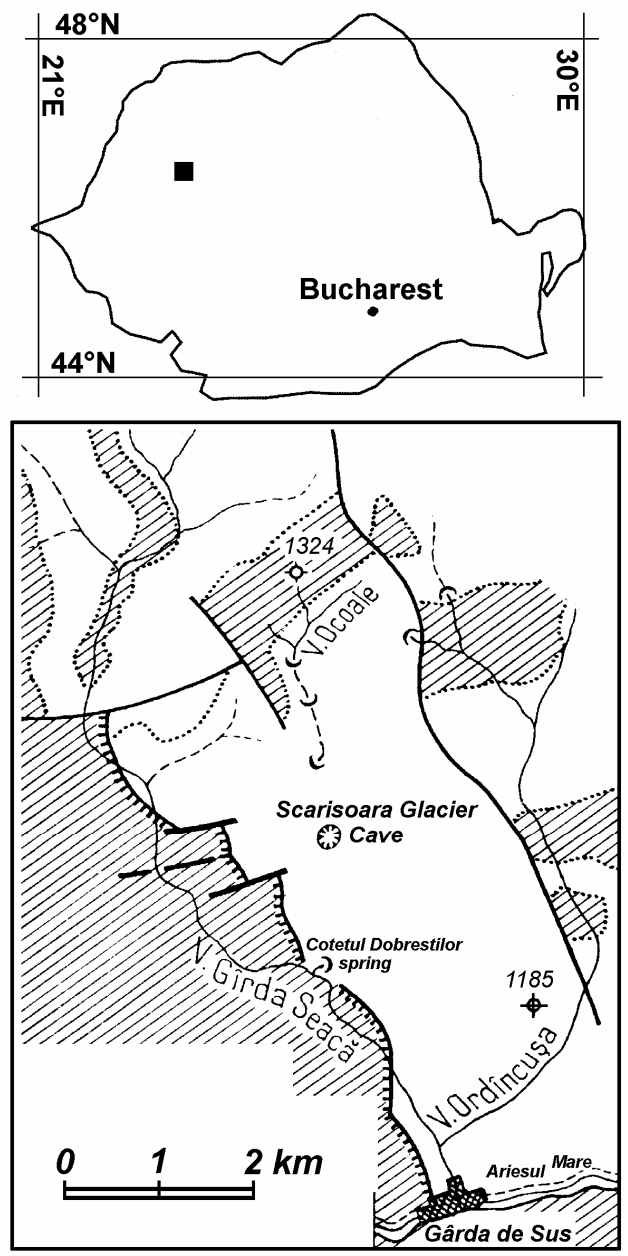

Fig. 1. Location of the Scărişoara Glacier Cave
The geological setting of the Ocoale - Ghețar Plateau is rather simple. The entire plateau is developed on Mesozoic sedimentary rocks belonging to the Bihor Unit ("autochthonous"). To the west, the Bihor Unit is overthrust by the Permian detrital formation developed in a Verrucanotype facies (purplishred colored quartzite sandstone, conglomerates, and shales). This latter one is part of the Gârda Nappe (Balintoni, 1997).

\section{Triassic vs Jurassic age of the limestone from Scărişoara Cave}

In 1964, the Geological Survey of Romania has published the geological map 1:100000, Arieşeni sheet, on which according to Bleahu and Dimitrescu the limestone around the Scărişoara Cave is of Triassic age (Ladinian and Carnian). Bleahu \& Dimitrescu (1964) presented these carbonate rocks as being massive reef limestone, locally dolomitized, and developed on Wetterstein facies.

After this map was released, all papers focussing on the geology of the Scărişoara Plateau considered the limestone around Scărişoara Cave to be of Triassic age.

The first ones to question the Triassic vs Jurassic age of these carbonates were Silvestru and Ghergari (1994) who sampled the limestones along the natural section provided by the cave. These samples were sent off to one of us (I.I. Bucur) to be analyzed with respect to their microfossil content. This preliminary study undertaken by Bucur on ten thin sections advocate for an Upper Jurassic age of the limestone.

Recently, a new set of limestone samples was collected from various locations of the cave. The sampled sites are presented in Fig. 2.

Microfacies and microfossils of the limestone from Scărişoara Cave The limestone samples we investigated show minor microfacies varieties. Most of them are relatively coarse biopelsparites (bioclastic-peloidal grainstones) (PI. I, Fig. 2$5)$, composed of skeletal fragments: plates and spines of echinoderms, bivalves and gastropods, worm tubes, scleractinian corals, bryozoans, and agglutinate foraminifera. 


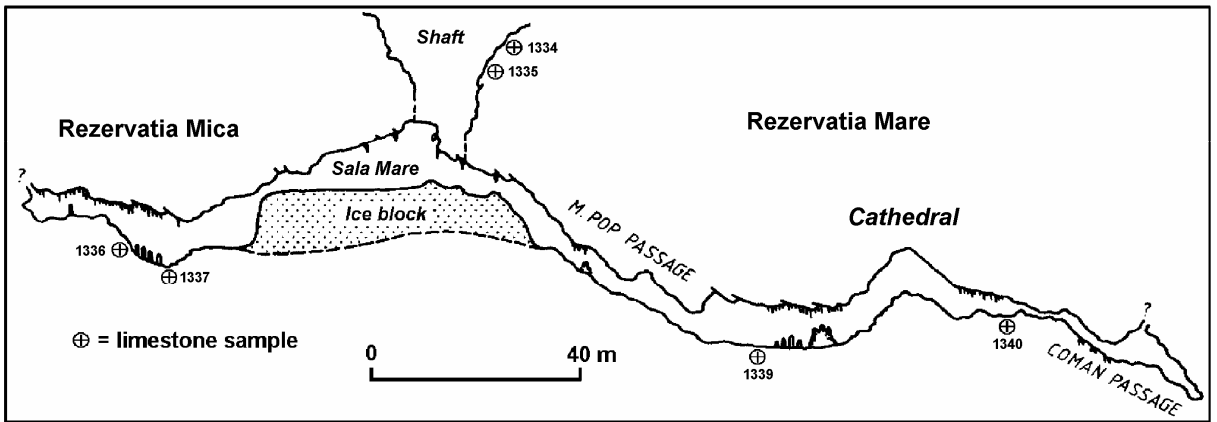

Fig. 2. Longitudinal cross-section through the Scărişoara Glacier Cave with the location of the limestone samples

Dasycladales, Bryopsidales and Rhodophyte algae are also present as well as "Tubiphytes" morronensis CRESCENTI and large fragments of microbial micrites of trombolithic type. Micrite peloids have both elongated-oval and irregular contour. Intraclasts of pelmicrite sediment are rare. Sparry calcite is the normally pore-filling cement.

Another microfacies type is the coral boundstones (PI. I, Fig. 1), made up of colonial scleractinian corals having their external surface covered by microbial crusts (including the "Tubiphytes" type) or by incrusted foraminifera. The voids between corals are filled with micrite sediment in which dasyclad algae are sometimes present.

The third type of facies is represented by well-packed bioclastic-peloidal grainstones (PI. I, fig. 6) showing elongated, flatten and oriented peloids. These appearances are most probable due to tectonic strain.

The limestone samples we analyzed are typical for a shallow marine carbonate shelf. Most probably they were deposited in its external zone (shelf edge). The microfacies of the limestone samples from Scărişoara are very alike to some sequences within the Cornet limestone (Padurea Craiului Mountains) also of Upper Jurassic age.

Most of the species identified within the micropalaeontological assemblage are characteristic for the Tethysian Upper Jurassic. The following foraminifers were determined: Andersenolina alpina (LEUPOLD) (PI. II, fig. 5), Troglotella incrustans WERNLI \& FOOKES (PI. II, fig. 4) and Labyrinthina mirabilis WEYNSCHENK (PI. II, fig. 1-3). Calcareous algae are represented by: Salpingoporella annulata CAROZZI (PI. II, fig. 6), Salpingoporella pygmaea (GUEMBEL) (PI. II, Fig. 7, 8; PI. III, Fig. 1), Linoporella capriotica (OPPENHEIMER) (PI. III, fig. 5), ?Suppiluliumaella delphica (CARRAS), Nipponophycus ramosus YABE \& TOYAMA (PI. III, fig. 3, 4), Thaumatoporella parvovesiculifera RAINERI and Solenopora jurassica NICHOLSON (PI. III, fig. 2).

Generally speaking, the assemblage is characteristic for the Upper Jurassic shallow water deposits of the Tethys Basin (Bernier, 1984; Senowbari-Daryan et al., 1994). From a biostratigraphic point of view, the most important species is Labyrinthina mirabilis. This species was previously cited by Fourcade \& Neumann (1965) from Kimmeridgian; Septfontaine $(1981,1988)$ from Oxfordian-Lower Tithonian; 
Pelissier et al. (1984) from Upper Oxfordian-Lower Kimmeridgian; Heinz \& Isenschmid (1988) from Upper Oxfordian-Kimmeridgian, Septfontaine et al. (1991) from OxfordianKimmeridgian and by Luperto-Sinni \& Masse (1994) from Kimmeridgian. Synthesizing all the knowledge over this foraminifer, Bassoullet (1997) consider that this species is characteristic for the Late Upper Oxfordian and Lower Tithonian (upper part, up to the base of the Middle Tithonian).

We can conclude that the age of the limestone around the Scărişoara Glacier Cave is definitely Upper Jurassic and not Triassic. Furthermore, the presence of the foraminifer Labyrinthina mirabilis allows us to precise the Kimmeridgian age of this limestone.

\section{REFERENCES}

1. Balintoni, I. (1997) - Geotectonica regiunilor metamorfice din Romania. Ed. Carpatica, 176 p., Cluj-Napoca.

2. Bassoullet J. P. (1997) - Foraminifères. Les grands foraminifères. In: Groupe français d'étude du Jurassique - Biostratigraphie du Jurassique ouest-européen et méditerranéen: zonations paralleles et distribution des invertébrés et microfossiles - Cariou, E. \& Haintzpergue P. (coord.) - Bull. Centre. Rech. Elf. Explor. Prod., Mém. 17, p.293-304, 3 tabl., Pau.

3. Bernier P. (1984) - Les formations carbonatées du Kimmeridgien et du Portlandien dans le Jura méridional. Stratigraphie, micropaléontologie, sédimentologie. Docum. Lab. Géol. Lyon, 92 (1-2), p.1-803, 218 figs., 21 tabl., 36 pls., Lyon.

4. Bleahu, M. \& Dimitrescu, R. (1964) - Harta geologică a R.P.R., foaia Arieşeni (1:100.000). Institutul Geologic, Bucureşti.

5. Fourcade E. \& Neumann M. (1965) - A propos des genres Labyrinthina Weynschenk, 1951 et Lituosepta Cati, 1959. Revue de Micropaléontologie, 8 (4), p. 233-239, 2 fig., 2 pls., Paris.

6. Heinz R.A. \& Isenschmid C. (1988) - Mikroifazielle und stratigraphische Untersuchungen im Massivkalk (Malm) der Préalpes médianes. Eclogae geol. Helv., 81 (1), p. 1-62, 19 fig., 7 pls., Basel.

7. Luperto Sinni E. \& Masse J. P. (1994) - Precisazioni micropaleontologiche sulle formazioni di Piattaforma carbonatica del Giurassico Superiore e del Cretaceo basale del massicio del Gargano (Italia Meridionale) e implicazioni stratigrafiche. Palaeopelagos, 4, p.243-266, 2 fig., 6 pls., Roma.

8. Pelissié B., Peybernès B. \& Rey J. (1984) - Les grands foraminifères benthiques du Jurassique moyen/supérieur du sud-ouest de la France (Aquitaine, Causses, Pyrénées). Intérêt biostratigraphique, paléoécologique et paléobiogéographique. In: Benthos '83, $2^{\text {nd }}$ int. Symp. Benthic Foraminifera (Pau, April, 1983), p.479-489, 5 fig., 2 pls., Pau.

9. Peters, K. F. (1861) - Geologische und mineralogische Studien aus dem südöstlichen Ungarn, insbesondere aus der Umgegend vom Réybánya. SitzungBer. Akad. Wiss. Wien, Math.-Naturwiss. Classe, 43(1), p. 385-463, Wien.

10. Racoviță, E. G. (1927) - Observations sur la glacière naturelle dite "Ghețarul de la Scărişoara". Bull. Soc. Sci. Cluj, III, p. 75-108, Cluj.

11. Racoviță, G. \& Onac, B. P. (2000) - Scărişoara Glacier Cave. Monographic Study. Ed. Carpatica, 139 p,. Cluj-Napoca.

12. Rusu, T., Racoviță, G. \& Coman, D. (1970) - Contributions a l'étude du complexe karstique de Scărişoara. Ann. Spéléol., 25, p. 383-408, Bucureşti.

13. Schmidl, A. A. (1863) - Das Bihar-Gebirge an der Grenze von Ungarn und Siebenbürgen. Verl. Förster u. Bartelmus, 442 p., Wien. 
14. Senowbari-Daryan B., Bucur I.I. \& Abate B. (1994) - Upper Jurassic calcareous algae from the Madonie Mountains, Sicily. Beitraege zur Palaeontologie, 19, p.227259, 2 fig., 1 tab., 11 pls., Wien.

15. Septfontaine M. (1981) - Les foraminifères imperforés des mileux de palte-forme au Mésozoique: détermination pratique, interprétation phylogénétique et utilisation biostratigraphique. Revue de Micropaléontologie, 23 (3-4), p. 169-206, 10 fig., 3 pls., Paris.

16. Septfontaine M. (1988) - Vers une classification évolutive des Lituolidés (Foraminifères) jurassiques en milieu de plate-forme carbonatée. Revue de Paléobiologie, Vol. Spec. №2 (Benthos '86), p.229-256, 5 fig., 2 pls., Genève.

17. Septfontaine M., Arnaud-Vanneau A., Bassoullet J.-P., Gusic I., Ramalho M. \& Velic I. (1991) - Les foraminifères imperforés des plates-formes carbonatées jurassiques: état des connaissances et perspectives d'avenir. Bull. Soc. Vaud. Sc. Nat. (Bull. 312 Lab., Géol., Géophys. et Musée géol. Univ. Lausanne), 80 (3), p.255-277, 2 fig., Lausanne.

18. Silvestru E. \& Ghergari L. (1994) - On the paleokarst in the cave Ghetarul de la Scărişoara (Bihor Mountains, Romania). Theor. Appl. Karst., 7, p. 155-161.

\section{Plate I.}

\section{PLATE EXPLANATION}

Fig. 1 : Coral boundstone. Sample 1334 (3), x 20.

Fig. 2 - 5 : Bioclastic-peloidal grainstones.

$$
\begin{aligned}
& 2 \text { - sample } 1339(3), \text { x 17; } \\
& \text { 3 - sample } 1335(1), \text { x 17; } \\
& \text { 4 - sample } 1339(1), \text { x 17; } \\
& \text { 5 - sample } 1339 \text { (2), x } 17 .
\end{aligned}
$$

Fig. 6 : Bioclastic-peloidal grainstone-packstone. Sample 1335 (2), x 20.

Plate II.

Fig. 1 - 3 : Labyrinthina mirabilis WEYNSCHENK.

$$
\begin{aligned}
& 1 \text { - sample } 1339 \text { (2), x 38; } \\
& \text { 2 - sample } 1339 \text { (4), x 38; } \\
& 3 \text { - sample 1337, x } 38 .
\end{aligned}
$$

Fig. 4 : Troglotella incrustans WERNLI \& FOOKES. Sample 1339 (2), x 70.

Fig. 5 : Andersenolina alpina (LEUPOLD). Sample 1339 (2), x 70.

Fig. 6 : Salpingoporella annulata CAROZZI. Sample 1339 (3), x 70.

Fig. 7, 8 : Salpingoporella pygmaea (GUEMBEL)

$$
\begin{aligned}
& 7 \text { - sample } 1335 \text { (1), x 38; } \\
& 8 \text { - sample } 1339 \text { (2), x 38. }
\end{aligned}
$$

Fig. 9 : "Tubiphytes" morronensis CRESCENTI. Sample 1339 (1), x 38.

\section{Plate III.}

Fig. 1 : Salpingoporella pygmaea (GUEMBEL). Sample 1334 (1), x 38.

Fig. 2 : Solenopora jurassica NICHOLSON. Sample 1339 (1), x 20.

Fig. 3, 4 : Nipponophycus ramosus YABE \& TOYAMA

$$
\begin{aligned}
& 3 \text { - sample 1337, x 20; } \\
& 4 \text { - sample } 1339 \text { (3), x } 38 .
\end{aligned}
$$

Fig. 5 : Linoporella capriotica (OPPENHEIMER). Sample 1339 (2), x 20. 


\section{PLATE I}
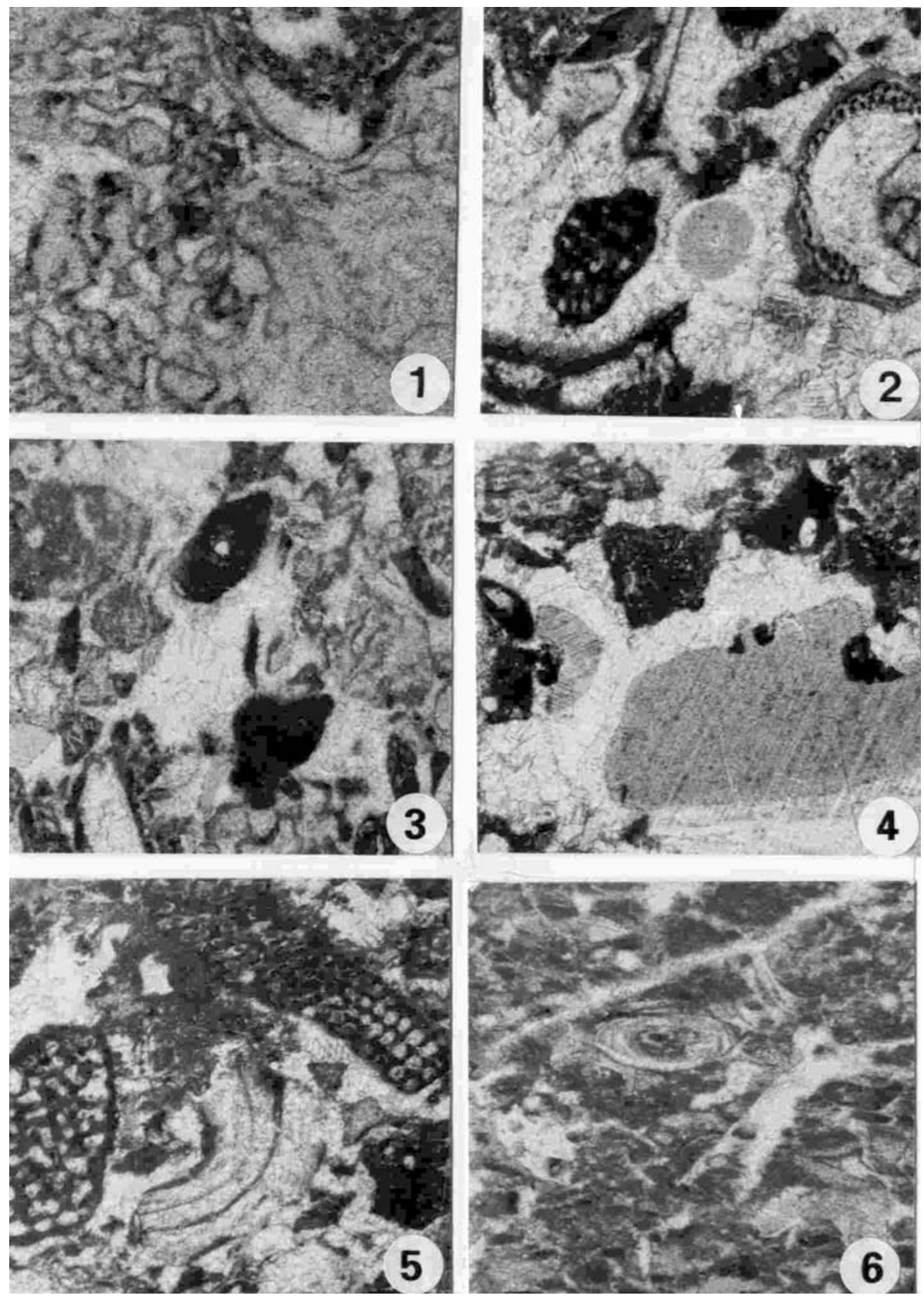
NEW DATA CONCERNING THE AGE OF LIMESTONE FROM SCĂRIŞOARA

\section{PLATE II}
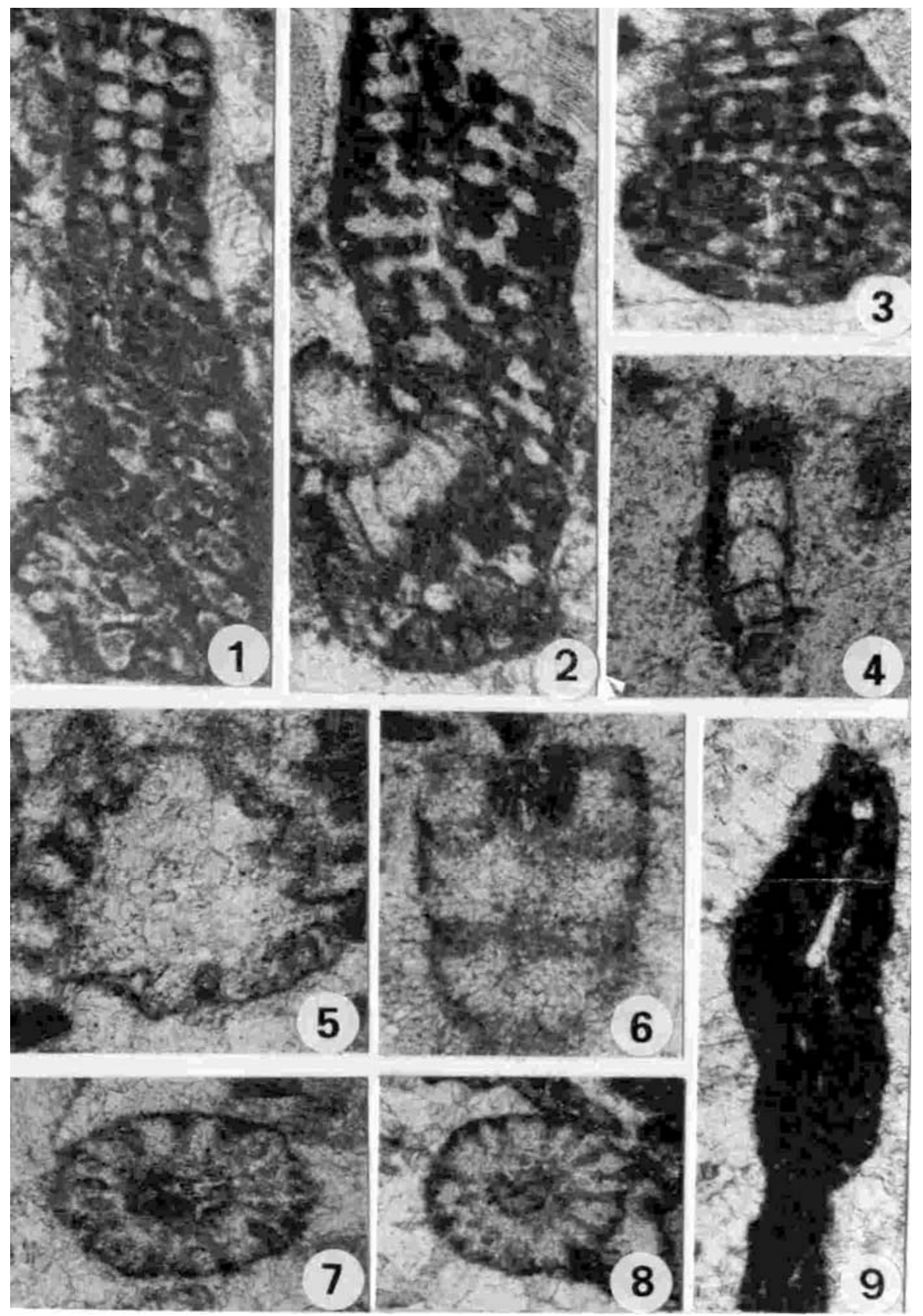
IOAN I. BUCUR \& BOGDAN P. ONAC

PLATE III
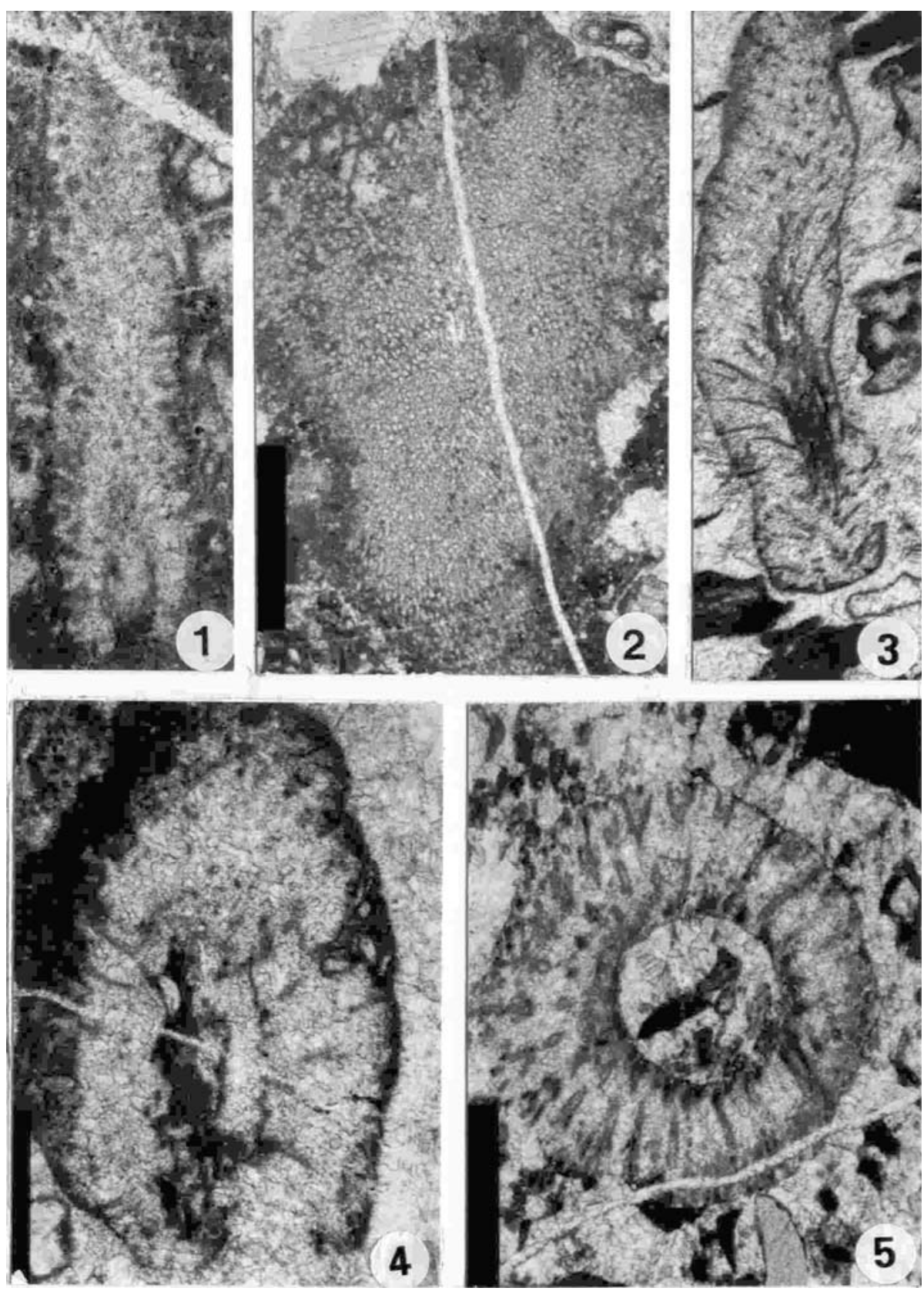